\title{
Fish species, traders, and trade in traditional market: Case study in Pasar Baru, Balikpapan City, East Kalimantan, Indonesia
}

\author{
RAHMAN LATIF ALFIAN ${ }^{1, \boldsymbol{v}}$, JOHAN ISKANDAR ${ }^{2,3}$, BUDIAWATI SUPANGKAT ISKANDAR $^{1}$, SUROSO $^{2}$, \\ DICKY P. ERMANDARA ${ }^{2}$, DEDE MULYANTO ${ }^{1}$, RUHYAT PARTASASMITA ${ }^{2,3}$ \\ ${ }^{1}$ Department of Anthropology, Faculty of Social Science and Political Science, Universitas Padjadjaran, J1. Raya Bandung-Sumedang Km. 21, Jatinangor \\ Unpad Campus, Sumedang 45363, West Java, Indonesia. Tel.: +62-22-2510276, Fax.: +62-22-7796974, `email: rahmanlatif927@ gmail.com, \\ budiawati.supangkat@unpad.ac.id \\ ${ }^{2}$ Department of Biology, Faculty of Mathematics and Natural Sciences, Universitas Padjadjaran. Jl. Raya Bandung-Sumedang Km. 21, Jatinangor Unpad \\ Campus, Sumedang 45363, West Java, Indonesia. Tel.: +62-22-779-6412, Fax.: +62-22-779-6412, `email: ruhyat.partasasmita@unpad.ac.id; \\ rp2010rikkyo@gmail.com; johan.iskandar@unpad.ac.id \\ ${ }^{3}$ Environmental Science Graduate Program (PSMIL \& DIL), Universitas Padjadjaran. J1. Sekeloa Selatan I, Bandung 40132, West Java, Indonesia
}

Manuscript received: 19 November 2019. Revision accepted: 4 January 2020

\begin{abstract}
Alfian RL, Iskandar J, Iskandar BS, Suroso, Ermandara DP, Mulyanto D, Partasasmita R. 2020. Fish species, traders, and trade in traditional market: Case study in Pasar Baru, Balikpapan City, East Kalimantan, Indonesia. Biodiversitas 21: 393-406. The purpose of this study is to analyze the species of fish traded by fish traders in the Pasar Baru traditional market, Balikpapan, East Kalimantan. In addition, this study analyses the Traditional Ecological Knowledge (TEK) of fish traders on fishes, including naming fish, fish habitat and caught technique, sex differentiate, taste of fish, price of fish, origin of fish and processing, freshness of fish and preservation, and the transmission of knowledge and conservation of the fish species. This study used qualitative methods that ethnoichthyology approach was used, with some field technics, namely observation, depth interview, and survey of species of fish were applied. The results showed that there were 36 species, representing 22 families recorded in the traditional market of Pasar Baru. Fish traders have good knowledge on fishes, including naming fish, sex differentiate, fish caught, freshness of fish, and how to preserve fish. Traders often offer fish to buyers by mentioning the names and various aspects of fish species, so the traders have indirectly introduced and socialized the TEK of fish species to buyers and a wider community. In addition, since the high diversity of fish species has normally traded in the traditional market, it has an important function not only for the community's economy, but also have an important function for the conservation of biodiversity of fish species in the region.
\end{abstract}

Keywords: Conservation, fish, traders, local knowledge, traditional markets

\section{INTRODUCTION}

Based on ecological history or environmental history, it has been a long time in various cities in Indonesia having traditional markets. Nowadays, although many modern markets have emerged, traditional markets in various cities in Indonesia are still able to survive. Traditional markets are places where traders and buyers meet or where demand and supply meet in buying and selling between traders and buyers (Supangkat-Iskandar 1998; Supangkat 2002). Traditional markets have characteristics, including simple physical conditions, buying and selling activities are realized based on the bargaining principle made possible by the sliding price system (sistem tawar menawar). In bargaining, social relations between traders and traders with buyers are activated, as well as a place for communication and information sharing between local residents.

In traditional markets, in addition to being traded various industrial city products, variety products of flora and fauna produced by rural farmers with a small-scale system are also predominantly traded. Among the diverse flora commonly traded in traditional markets, namely in the form of edible plants, such as fruits, vegetables, cooking spices, and traditional medicinal plants (Arman 1996; Supangkat 2012; Silalahi et al. 2015; Iskandar et al. 2018). Meanwhile, variety products of fauna commonly traded in traditional markets, including various species of fish, such as salted fish and fresh fish produced from the sea or freshwater ecosystem (Supangkat 2002; Nurasa 2005; Maidika et al. 2016; Kurniawan et al. 2019).

The variety of flora and fauna products traded in traditional markets is closely related to the culture of the local community and the diversity of local biodiversity. For example, the diversity of dominant vegetable species has been traded in some traditional markets, such as the Ujung Berung market, Bandung, West Java. This is partly because culturally Sundanese people like to consume both fresh and cooked vegetables and some mountainous areas in rural West Java have become vegetable farming centers because the area is suitable for vegetable cultivation, such as having fertile soil and appropriate cold weather (Iskandar et al. 2018). Similarly, a variety of fruits have been widely traded in several traditional markets in Pontianak, West Kalimantan, partly because of having the diversity of fruits produced by small-holders in mixed orchards or forest gardens (Tembawang) (Arman 1996). Therefore, the diversity of flora and fauna products traded in traditional 
markets is a reflection of the diversity of biodiversity and the cultural characteristics of the people in the region (cf. Albuquerque et al. 2014).

Because various products of flora and fauna have commonly traded in traditional markets, the traditional markets can play an important role, not only for the function of the people's economy, but also for the conservation of various biodiversity products. Indeed, the local rural people want to cultivate or conserve the species of flora and fauna in their area due to those species flora and fauna may be traditionally traded in the traditional markets. In addition, the traditional markets may also play a role in maintaining and transmitting the local knowledge or the Traditional Ecological Knowledge (TEK) of traders on various species of flora and fauna. Because the traders who have been owned experience trading the species of flora and fauna for a very long time and transmitted through generations, causing them to have knowledge of TEK about flora and fauna.

Therefore, the traditional markets can be considered to be essential play an important role, not only for the function of the people's economy, but also for the conservation of various biodiversity products. In addition to giving encouragement to farmers to cultivate and conserve the flora and fauna in their area, the traditional markets can also play a role in maintaining and transmitting TEK of the local people on species of flora and fauna. Since the traders who have been experienced trading the species of flora and fauna for a very long time and inherited through generations, they have culturally owned and maintained the TEK of flora and fauna.

Generally, the traditional market across culture in many regions can be considered as public places designated for various flora and fauna products that simultaneously function as spaces for trade and cultural information, including TEK of flora and fauna (cf. Alburquerque et al. 2014). TEK may be defined as unique to given culture or society, as cumulative body of knowledge, practice, and belief, evolving adaptive process and handed down through generations by cultural transmission. Conversely with the scientific Western knowledge system which is generally through the global network universities and research institutes (Warren et al. 1995; Ellen and Harris 2000; Sillitoe 2002; Berkes 2008). Skill of local traders of trading flora and fauna, for example, can only be learned particularly by 'hand-on hand instruction from parents, elders or peer group among traders, and their specialized vocabularies, which go with each of these activities. It appears that the use of native terms associated with place, based on subsistence activities, including trading of flora and fauna. Therefore, language and oral tradition are essential to link in the traditional knowledge and serve an intergenerational taint of thought (Edwards 2010; Nabhan 2016). Nowadays many scholars believe that TEK and beliefs, and practices have much to contribute to the conservation of biodiversity as well as sustainable use of natural resources (Carlson and Maffi 2004).

Although traditional markets in many regions of Indonesia as a predominant place to trade in a variety of flora and fauna are closely cultural, and can be a transmission of local knowledge or TEK on a variety of flora and fauna, study of the local knowledge of traders in traditional markets about the species of fauna, such as species of fish based on ethnoichthyology approach, as sub-discipline of ethnozoology and ethnobiology (Alves and Souto 2015) are still rarely conducted in Indonesia. The prefix ethno in 'ethnoichthyology' is used to denote a field of knowledge defined from the viewpoint of the people being studied and is similar in meaning to the term folk, as in the folk of knowledge, in this case on fishes (Milton 1996; Fowler 2000; Brown 2000; Carlson and Maffi 2004). This study tries to elucidate the knowledge of fish traders in the traditional market of Pasar Baru, Balikpapan, East Kalimantan, on various aspects of the fresh fishes they trade. The research objective is to examine the species of fish fresh traded and various traders' knowledge about fish that are being traded, such as fish names, fish habitat, fishing techniques, fish management in traditional market of Pasar Baru; and the role of traditional markets as the transmission of knowledge about fish fresh and biodiversity conservation fish. In this study, the term 'fish' for further use of 'fresh fish' does not belong to the category of salted fish.

\section{MATERIALS AND METHODS}

\section{Studi sites}

This research was conducted in traditional market of Pasar Baru Balikpapan, which is administratively located in Kelurahan Kladasan Ilir, Balikpapan Kota District, Balikpapan City, East Kalimantan (Figure 1).

The Balikpapan Kota District has an area of $10.21 \mathrm{Km}^{2}$ with has population of 90,645 people, consisting of 46,771 males and 43,874 females. Thus, population is slightly dominated by females. Balikpapan Kota Subdistrict consists of 5 kelurahan, namely Prapatan, Telagasari, Klandasan Ulu, Klandasan Ilir, and Damai. Balikpapan Kota District is bordered by several other neighboring regions (Central Bureau of Statistic of Balikpapan City 2018) namely; Central Balikpapan District to North, South Balikpapan District to East, Makassar Strait to South, and Central Balikpapan to West.

Traditional market of Pasar Baru Balikpapan is located in Kelurahan of Klandasan Ilir. Distance to the center of Balikpapan Kota Sub-District about $3 \mathrm{Km}$. Traditional market of Pasar Baru is not the only market in Balikpapan Kota District. Not far from the location of traditional market of Pasar Baru Balikpapan, there is also the Klandasan Market which is located in Kelurahan of Klandasan Ulu and only about $1 \mathrm{Km}$ from traditional market of Pasar Baru Balikpapan. The two markets are traditional markets but under different management. Traditional market of Pasar Baru Balikpapan is managed by a private party namely PT. Hasta Kreasi Mandiri, which in its management always coordinates with the Balikpapan City government. Meanwhile, the Klandasan traditional market is managed by the Balikpapan City government under the Balikpapan City Trade Office. 
Traditional market of Pasar Baru Balikpapan was chosen as a research area because of its socially strategic location. It is located not far from the city center of Balikpapan, which is only $1.8 \mathrm{Km}$ away from the Balikpapan Municipality's office. Traditional market of Pasar Baru is also not far from Sultan Aji Muhammad Sulaiman Sepinggan Airport, which only takes 20 minutes when taken by motorized vehicles. Besides being not far from the airport, the location of traditional market of Pasar Baru Balikpapan is also not far from Semayang Port which is a port in the city of Balikpapan which is only $4.8 \mathrm{Km}$ away or only takes 15 minutes when taken by motorized vehicle. This strategic location makes traditional market of Pasar Baru Balikpapan a destination for local residents and migrants to try their making money at trading to meet their daily needs. As a result, the traditional market of Pasar Baru can be considered as one of the city market centrals in Balikpapan, East Kalimantan.

Based on the background of origin of traders in the traditional market of Pasar Baru Balikpapan is very diverse, which comes from Penajam; South Sulawesi, like Makassar; Banjarmasin; Java; Madura; and Sumatra, like the Minang people. The large number of migrants who trade in traditional market of Pasar Baru, also brings the origin of the knowledge they have from their experience and culture. This is one of them which is the foundation in seeing the knowledge of traders, especially fish traders in the mention of local names and various knowledge about the fish species being traded.

\section{Research procedures}

Study method used in this study was qualitative approach in which ethnoichthyology of ethnozoology subdiscipline was used (Albuquerque et al. 2014a,b, Iskandar 2018). Ethnozoology emerged from the field of ethnosciences, and seeks to understand how the world's different people have perceived and interacted with fauna resources throughout history. It is hybrid discipline structured with combination of elements from both the natural and social sciences, including biology and anthropology (Alves \& Souto 2015).

Some techniques for collecting field data, namely observation, recording of types of fish, and semi-structural interviews or deep interviews were applied. Observations were undertaken to get a general picture of local market conditions and the situation of fish trade in the traditional market of Pasar Baru, Balikpapan, East Kalimantan. Observations were conducted by researchers visiting the market repeatedly many times for a month. The visits were conducted in the morning until noon during the busy market is taking place.

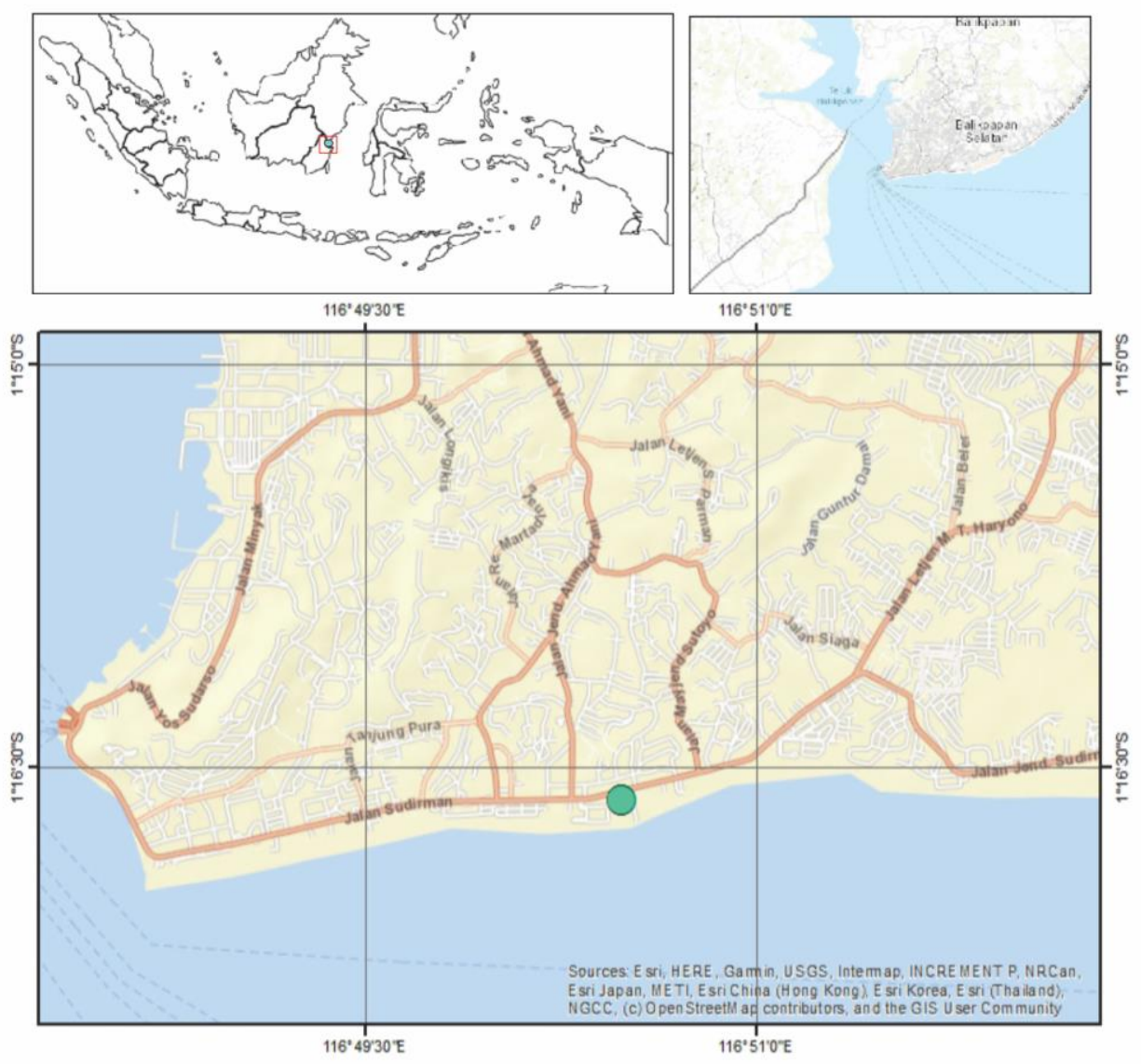

Figure 1. Map of study site: Traditional market of Pasar Baru, Balikpapan, East Kalimantan, Indonesia. Source: Adapted from Google Map (2019) 
Survey of fish was carried out to identify the species of fish traded by fish traders in Pasar Baru, Balikpapan. To identify the species of fish, several books for fish identification, including Schuster and Djadiredja (1952); Sawada (1980); Kottelat et al. (1993), and White et al. (2013) were used. To validate each fish species, documents and photographs of fish traded in Pasar Baru were taken and analyzed in the Laboratory of the Animal Systematic Laboratory, Department of Biology, Faculty of Mathematics and Natural Sciences, Padjadjaran University.

Semi-structured interviews or deep interviews were conducted with competent informants who are selected purposively with regard to differentiates. Some informants, including some fish traders were chosen with various variations based on the species of fish that was dominantly traded, namely male and female traders selling fish of "layur" (traded of layur), "alo-alo/alu-alu", gembong/kembung, tenggiri, kerapu, tuna, etc. Interviews were also carried out with other informant categories, such as, fish buyers, market management fish buyers, workers of carrying fishes from the port to traditional market, and the traditional market management staff. In the semi-structure interview, informants gave intensive responses to a series of general questions, some of which have been prepared in advance and some of which arise naturally during the course of conservation.

\section{Data analysis}

Data analysis used four activities namely data collection, data reduction, data presentation, and drawing conclusions or verification (Miles and Huberman 1992; Newing et al. 2011). The process was carried out repeatedly to get a certain pattern in the community under study. In conducting data analysis, the flow was not always sequential because these steps are intertwined at the time before, during, and after data collection in a parallel form, to build a general insight called analysis. To identify species of fish from fish samples and photographs of fish carried out in the Animal Taxonomy Laboratory, Department of Biology, Faculty of Mathematics and Natural Sciences, Padjadjaran University.

In the analysis for data verification, researchers used triangulation. Where researchers compare the data of observations with data obtained at the time of the interview. The researcher also compared interview data from one informant to another. In addition, the results of this field study were also analyzed with some literature.

The results of field data that have been carried out by cross-checking were then summarized, synthesized, and narrated in descriptive analysis and evaluative (Newing et al. 2011).

\section{RESULTS AND DISCUSSION}

\section{Situation of traditional market of Pasar Baru}

The traditional market of Pasar Baru Balikpapan or the local community knows it by the name of 'Pasar Balcony'.
General description of the entrance gate (Figure 2), as well as general description on the outside and inside the market, are shown in Figure 3.

The mention of Balcony itself refers to the name of the shopping center above it, Balcony City before changing its name to Balikpapan Ocean Square. The traditional market of Pasar Baru itself is located in the basement area of the shopping center. This makes many people know him by the name of Pasar Balcony.

It is not known exactly how this market history was built. Not yet found in real documents that discuss the history of the traditional market of Pasar Baru Balikpapan in the past. But some of the stories compiled from market traders are believed to have existed from the 1970s.

The informant traders told me that Pasar Baru had caught fire several times. At first, Pasar Baru was located more forward than the current location, more precisely on the edge of the highway. This market was not formally developed by the government but rather as a gathering of migrants who opened wooden shanties to trade. Traders said that not many stalls were built permanently, most stalls and stalls were made of wood. They also illustrated that the condition of the New Market at that time was a market that was less organized and full of simplicity. This is what makes Pasar Baru several times experienced a fire, because the material used to set up stalls or stalls is made of wood so it is flammable.

Due to the limitations of written documents and photographs of the past of Pasar Baru, the stories that surround them are also varied. Nevertheless, from the traders' stories, the researchers had the opportunity to see how the traders interpreted traditional market of Pasar Baru as the location they lived in and where they lived.

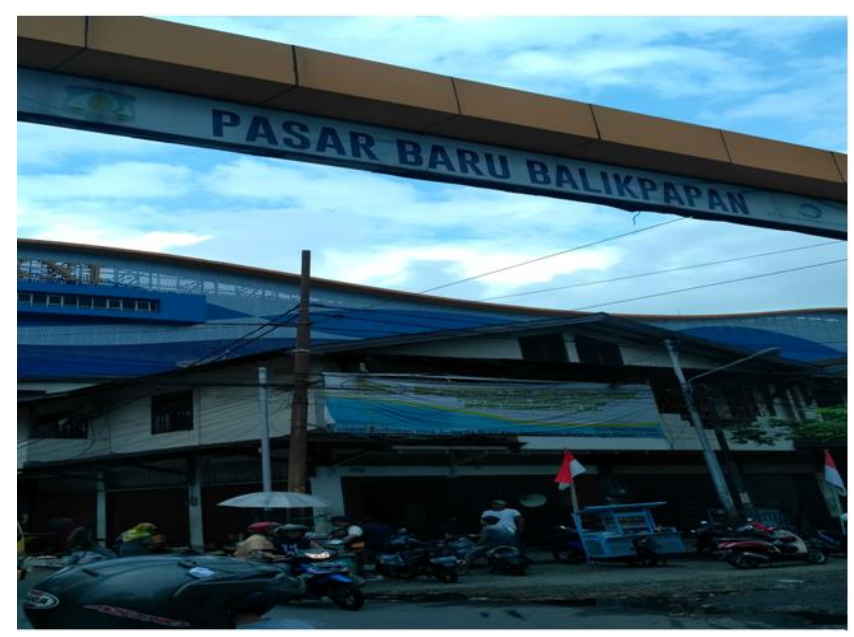

Figure 2. The gateway for entering traditional market of Pasar Baru, East Kalimantan, Indonesia 

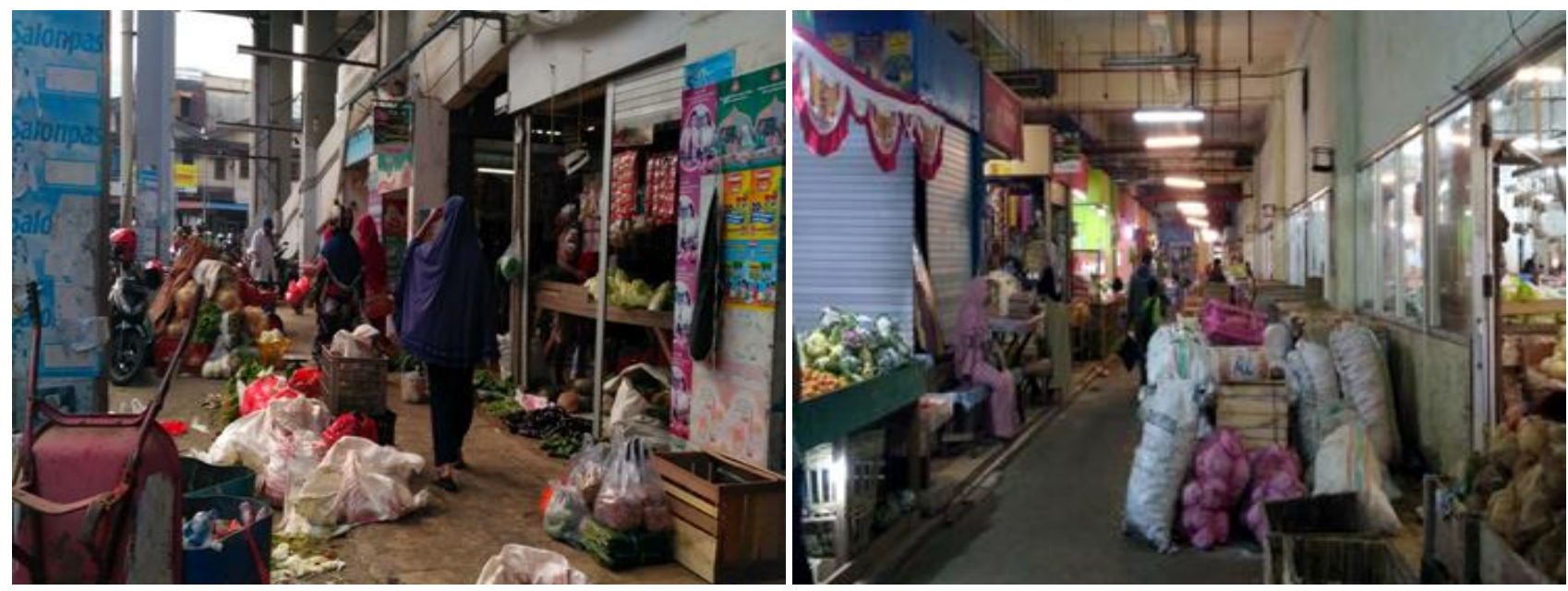

Figure 3. General situation of the outside (left) and inside (right) of the traditional market of Pasar Baru, Balikpapan, East Kalimantan, Indonesia

As mentioned earlier, traditional market of Pasar Baru Balikpapan is located in Kelurahan of Klandasan Ilir, subdistrict of Kota Balikpapan, Balikpapan City. At the moment, traditional market of Pasar Baru is managed by a private party, PT. Hasta Kreasi Mandiri in collaboration with the government. The private sector is also the manager of the shopping center above traditional market of Pasar Baru which is now named 'Balikpapan Ocean Square'. The traditional market of Pasar Baru is located in this basement, according to traders, it began in 2013. While management by the private sector itself began in the last 2 years. According to the market manager, collaboration between the private sector and the City of Balikpapan in managing the traditional of Pasar Baru is because it was launched as a traditional market pilot market that blends with modern shopping centers. Why is it also called collaboration because the city government of Balikpapan also continues to oversee the operation of the traditional market of Pasar Baru Balikpapan?

Unlike the traditional markets in general, the location of traditional market of Pasar Baru is located in the basement of a shopping center and hotel. This gives a different impression when first entering the market location. Stalls and shanties are mostly illuminated by lights, sunlight does not enter the market so that when there is no lighting the market lights tend to be pitch black. On the roof of the market, air ducts and water pipes are connected to the shopping center above. Inside the traditional market of Pasar Baru consists of blocks ranging from block A to block $\mathrm{H}$, each block is still subdivided such as block A-1, block C-3, block G-2, and so on. Even so, the arrangement of the kiosk is not based on certain blocks, or in other words, there is no categorization. Stores, stalls and stalls of traders in traditional market of Pasar Baru sell various types of merchandise, such as stalls of nine basic staples (groceries), vegetable stalls, fish stalls, vegetable stalls, fruit stalls, coconut milk stalls, clothing stores, food stalls, and so forth. As mentioned earlier, the various types of stalls are random, there is no standard food stall to be in which block.
The traditional market of Pasar Baru is opened every day, there are no market days in the Pasar Baru open system. The market is usually crowded in the morning. After dawn until $07.00 \mathrm{pm}$ Central Indonesia Time (CIT) is the busiest time in market activities every day. Even so on Sundays or holidays, the market crowd will be even longer, namely until 10:00 pm CIT. After this rush hour, traders do not necessarily close the stall. These traders will remain open until after 12.00 am CIT or even later. Some traders still open their shops until the afternoon or at $16.00 \mathrm{pm}$ CIT. But most of the merchants began to sell their wares after hearing the dhuhr prayer. The loading and unloading process in Pasar Baru consists of two times, evening and morning. In the afternoon the process of loading and unloading vegetables is usually carried out, the demolition is carried out on the deck east side of the market. Delivery of vegetables is done in the afternoon because the traders will sort the goods before the next morning is sold to consumers. Meanwhile, for the morning most of the shipment of meat and fish commodity unloading. The delivery of meat and fish is done in the morning intended to have the meat and fish received fresh and then directly sold to consumers in the market.

Most of the traders in Pasar Baru Balikpapan are migrants from outside the Balikpapan area. These migrants came from Banjarmasin, South Sulawesi (Makassar), Java, Madura, and Sumatra (like Minangkabau). There is no definite rule for traders from certain regions to trade certain goods. But these traders usually sell merchandise that is familiar in the culture and life in their place of origin. Like most tempe sellers are Javanese, ground spices (bumbu giling) sellers are Minang, and most fish sellers are South Sulawesi. Each trader carries different knowledge according to the culture they received at their place of origin. Nevertheless, such knowledge also mingles with the prevailing customs in traditional market of Pasar Baru. For example, in selling eggs, one of the egg sellers found at Pasar Baru came from Surabaya. In their original place eggs are sold per kilogram, but in Pasar Baru eggs are sold per item or per 30 eggs. The seller also adjusted the habits 
of the people in traditional market of Pasar Baru.

Although traders in Pasar Baru have different cultural backgrounds, there has never been a conflict in Pasar Baru. The same feeling as fellow migrants makes these traders build harmony with all traders. This can be seen from the close interaction between traders that occurs in Pasar Baru. For example, when the market has begun to quiet, while organizing merchandise, not a few traders who mingle with one another. In addition, these traders also help each other, for example, when a trader wants to go for a while to look for something, the kiosk will be guarded by traders who are not far from his kiosk. They also help each other when one of the merchants runs out of goods that consumers want to buy, then the trader will find it to other similar traders.

\section{Fish trade and Fish Trader in Pasar Baru}

The fish seller block in traditional market of Pasar Baru was built in the form of a room inside the market. This room is quite large because it accommodates fish traders, beef and chicken traders, and vegetable and banana sellers. This block space is limited by a wall that has 7 doors as access to enter and exit the block. On the wall is equipped with glass that makes visitors outside can see the contents in the room. Specific locations for selling fish are located in the East, at that location, there are 2 doors, namely the East door as the main access from outside the market and the Northside door that connects with other parts of the market (Figure 4).

The location to sell fish is built with white ceramic flooring and consists of permanent shanties that extend on white tiles. In these stalls, fish traders line up, each trader has a stall area of around $1.25 \times 0.75 \mathrm{~m}$. Each merchant's stall is marked by a scale that is hung on each stall. Each trader has a scale that is used to weigh fish. The atmosphere that is felt when entering this fishmonger block is the bright lights that are indeed different from other blocks. The lights used by fishmongers are brighter compared to stalls outside the block. The atmosphere was brighter because of the lights installed by the manager on the roof of this block. In addition, the characteristics at the fish market are wet, muddy and a bit slippery. The wetness of the floor comes from the melting of ice cubes which is used to maintain the freshness of fish, besides that fish sellers also regularly flush the fish they sell with ice water to always look fresh. This ice water that soaks the floor in the fish block makes the ceramic-coated floor become slightly slippery.

In trading fish in Pasar Baru, 3 main stakeholders are involved: fish traders, coolie carrying fish, and fish consumers. The involving and activities of these stakeholders in trading fishes are elaborated as follows.

Fish traders in traditional market of Pasar Baru are believed by traders to have existed since the beginning of the market opening. Until now traders did not know exactly what year traders began trading in the market. One of the informants argued that "if the fish traders here have been around since this market existed, that fish is one of the tasty and special side dishes in Balikpapan, fish are also cheap".

Most fish traders in Pasar Baru Balikpapan are migrants from South Sulawesi. Nevertheless, there are still fish traders who come from other regions but the numbers are very few.

Everyday fish traders in Pasar Baru Balikpapan start to open their stalls at 04.00 am CIT (Figure 5). Arriving at the market, fish traders start to open the shanties, which are preceded by installing lights in each stall (Figure 6). Installation of lights other than intended as lighting is also intended as an attraction, because good lighting will make the fish look attractive. Fish traders' stalls in the morning are usually already in a clean and dry condition, this is because every afternoon or evening before returning home the traders will clean each of their stalls. After installing the lights, traders began removing equipment such as scales, plastic bags, and cutting tools such as knives. Soon fish traders will take out of the cooler, under the stalls of their wares. Some traders, especially large fish sellers, store fish cooler boxes outside the fish block, the boxes are placed near the entrance and loading and unloading locations located on the east side of the Fish Block. The traders then arrange the fish to be sold that day. After the dawn prayer, the traders are usually ready to sell prearranged fish.
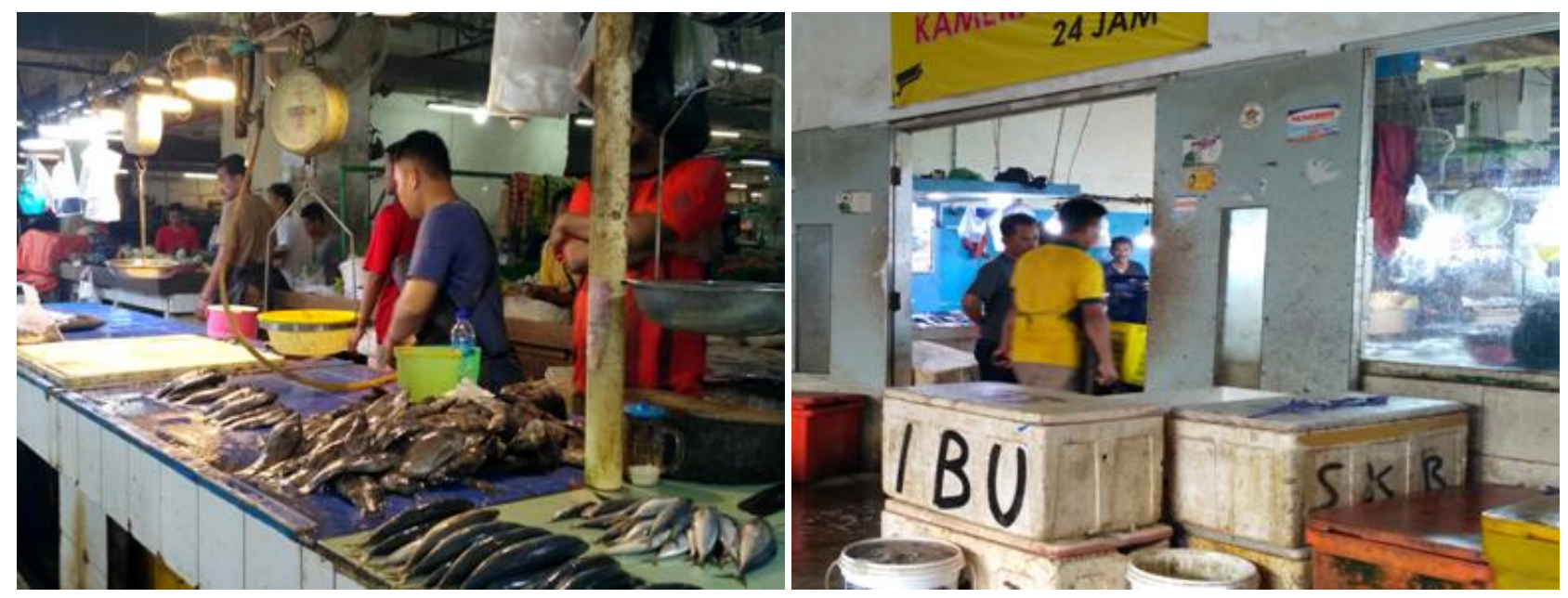

Figure 4. Fish trader stalls (left) and east entrance of the fish seller block (right), Pasar Baru Balikpapan, East Kalimantan, Indonesia 


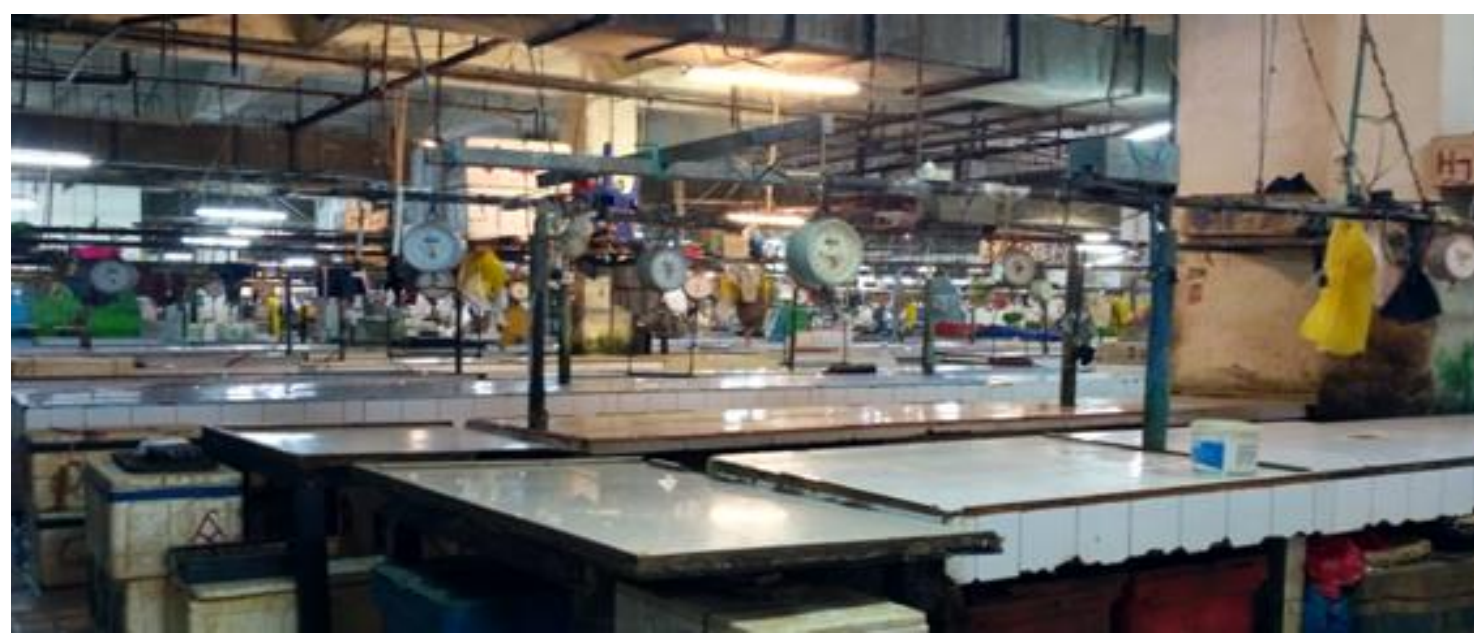

Figure 5. The situation of the fish block before trading activities begun

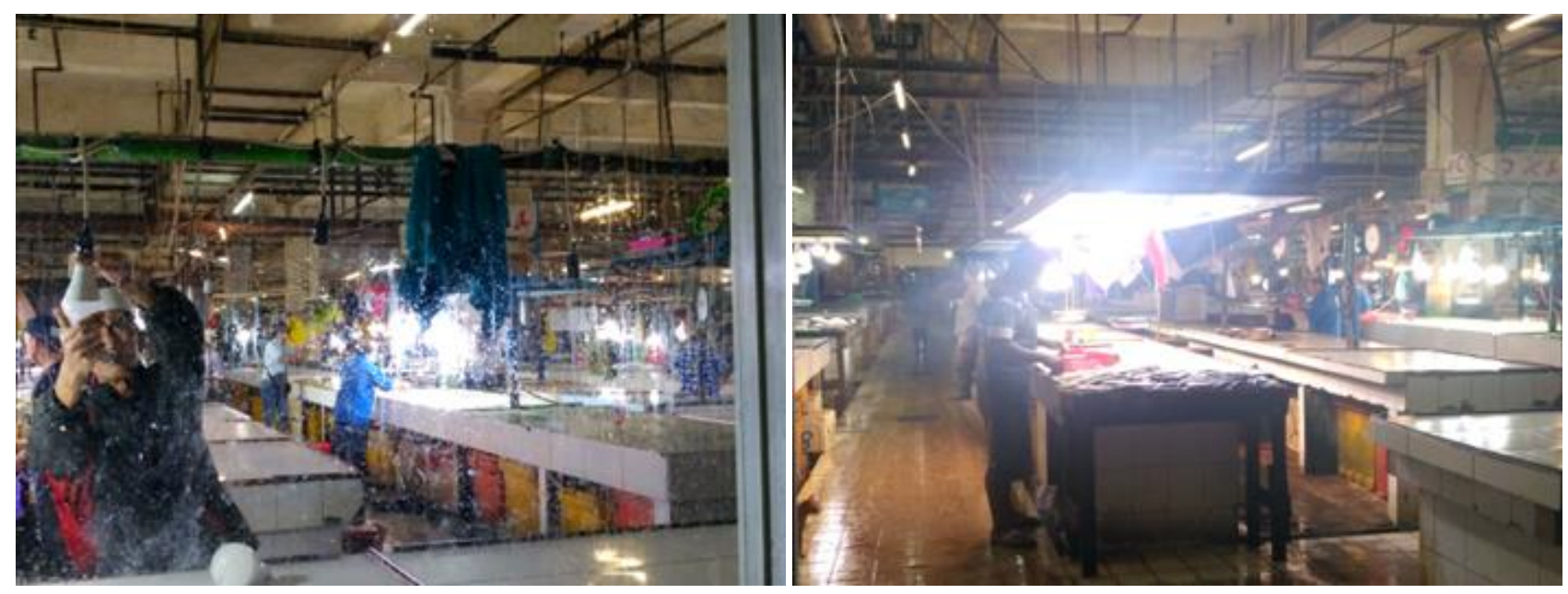

Figure 6. Activities before starting the fish trade installing lights (left) and arranging fish (right) on the table

Fish traders in the traditional market of Pasar Baru sell fish with a weigh system or traders call it the 'kilo' system. The benchmark price of fish is determined per kilogram, it is intended to facilitate the calculation of the purchase price and selling price of fish traders. The price of fish in the traditional market of Balikpapan tends to be stable, this is because the supply of fish in Balikpapan is always maintained. However, in certain months the price of fish can go up or down, this is influenced by the availability of fish on the market. The origins of where fish are obtained also influence the buying and selling prices of fish in Pasar Baru. The price of fish will be cheaper if the fish is obtained from fishermen or the sea around Balikpapan, such as fish supply from Manggar fishermen who are local fishermen in Balikpapan. On the contrary if the supply of fish comes from outside the Balikpapan area, such as frozen fish from Surabaya, the price will be more expensive if sold because the purchase price is above the price of local fish supply. Fish traders receive greater supply from fish traders (middlemen) usually at the port or Fish Auction Place (Tempat Pelelangan Ikan-TPI). At present, fish sellers in the market simply call 'middlemen' (or they call it 'skipper') if they need delivery of fish stocks. Meanwhile, for the occasional payment, the skipper comes to the market to collect the fish money that has been purchased. Some traders sometimes also entrust money to subordinates or motorcycle taxi drivers in charge of sending fish to the market. But if the nominal is large, then the skipper himself will take the money to the fish seller in the market.

Fish traders in Pasar Baru sell fish of various sizes, most of the fish sold are sea fish. Traders sell small-sized fish such as ikan biji nangka (Pterocaesio chrysozona), medium-sized fish such as ikan kembung (Rastrelliger sp.) Or better known as mackerel fish, or large fish such as ikan trakulu or ikan kwe (Caranx ignobilis) or ikan tenggiri (Scomberomorus sp.) and ikan alo-alo or ikan barracuda (Sphyraena sp.) (Figure 7). 

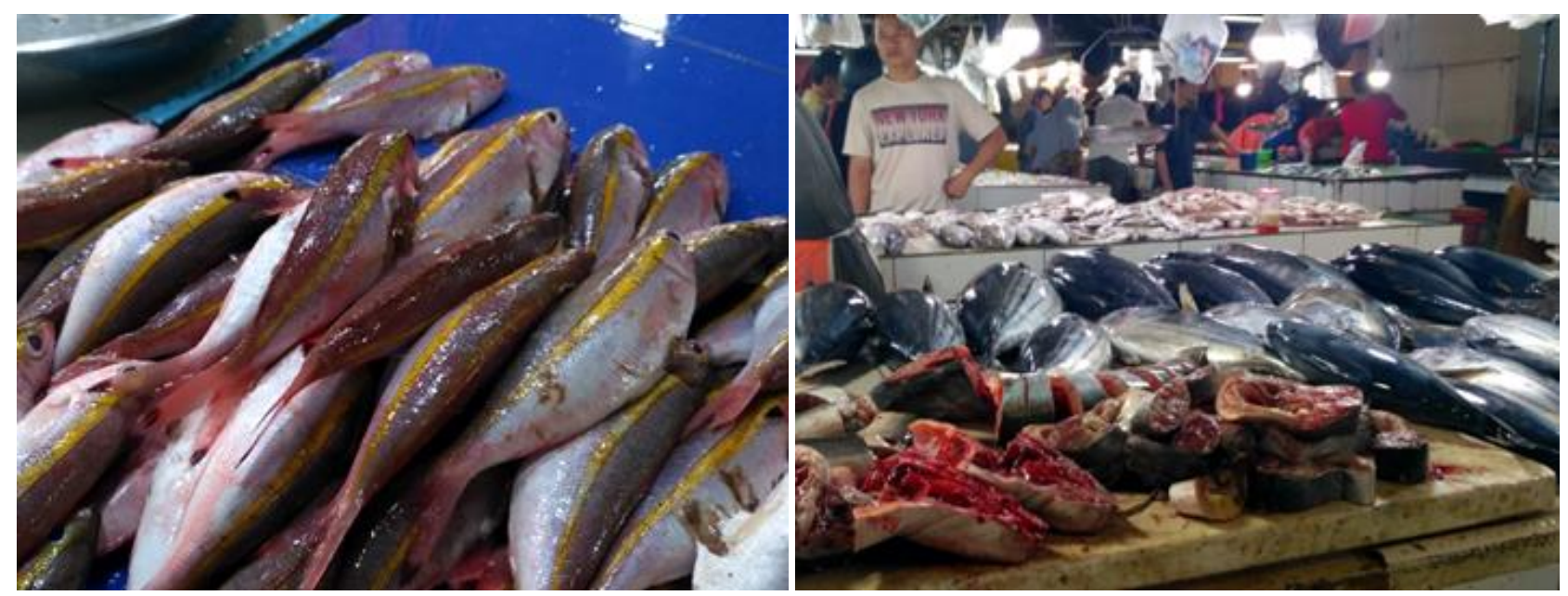

Figure 7. Fish of biji bangka (Pterocaesio chrysozona) (left) and fish of tongkol (Euthynnus affinis) sold in the form of cut (right)

Especially for large fish sales, traders sometimes also serve sales in the form of pieces, so they don't have to buy one. This is because large fish can weigh several kilograms, so it is too much for family consumption to buy one whole. However, sometimes there are also consumers who buy large whole fish, usually purchased for party meals or large family meals. The price per kilogram sold as a whole will be cheaper when compared to in the form of cut. For example, the fish Trakulu, the price in the form of one fish is Rp. $40,000 / \mathrm{kg}$ while the price in the form of a cut is Rp. 50,000/ kg

Fish trading activities in Pasar Baru are busy in the morning. Before 09.00 am CIT is the busiest time in fish trading activities in Pasar Baru Balikpapan. After that time, there are still consumers who buy fish but the conditions are not as busy as before. Fish traders in Pasar Baru Balikpapan sell every day, every day these traders sell until noon. Usually at 11.00 am CIT, fish traders began to decrease, some had already closed their shanties, and some had just packed, cleaned and loaded the remaining fish from the day's sales into the cooler. When the time showed 12.00 am CIT or after zuhr, the fish traders had closed their shanties. The activity of buying and selling fish in Pasar Baru can be said to have been completed on that day. Traders usually close the day's activities by calculating the cost of transportation with porters who previously raised fish from the sender to the shanties where they sell. The traders will also pay ice cubes to the ice seller, when trading or before closing the traders usually ask for ice cubes to preserve the remaining fish on sale that day. The purchase of ice is intended so that fish can still be sold the next day.

\section{Fish buyers in Pasar Baru}

Consumers who buy fish in the traditional market of Pasar Baru Balikpapan are divided into two groups, namely fish buyers who are then resold and fish buyers for personal consumption. Fish consumers as personal consumption usually buy fish in the morning starting at 06.00 am Central
Indonesian time (CIT). On weekdays (Monday-Friday) not a few consumers who shop even earlier, namely after dawn prayer time or at 05.00 am CIT. Personal consumers come from the area around Pasar Baru Balikpapan.

On the other hand, fish buyers at Pasar Baru Balikpapan also buy for resale. These buyers usually work as mobile vegetable sellers or locals call them motor vegetable traders (pedagang sayur motor). This vegetable traders usually use a motorbike equipped with a kind of basket in the back seat. Motorcycle vegetable traders start shopping earlier than private consumers. Some motorcycle vegetable traders have even arrived at the market before dawn or 03.30 am CIT. This is because motor vegetable traders have to shop for vegetables, fish, meat, fruit, and the needs of goods to be sold later. Arriving at the market so early is also intended to get goods at lower prices and fresh conditions.

The arrival of these buyers is earlier, after arriving they will park their motorbike around the loading location while waiting for the fish seller to open their shanties. While waiting for the vegetable seller, the motorbike will prepare "brojong" (shells mounted on the motorbike), while sorting the merchandise leftover from the previous day so that it can be sold again on that day. These traders will enter the fish block after dawn or after the fishmongers open the shed and are ready to sell. These vegetable traders are easily recognizable by the attributes used, namely most motorcycle vegetable traders use small sling bags that are used to save money. In addition, motor vegetable traders can also be identified from groceries purchased in large quantities and divided into several plastic bags.

Motorcycle vegetable traders buy fish in the market in greater quantities when compared to individual consumers. This is a large amount because the fish purchased will be sold back to the villages or other regions. The amount of fish purchased by vegetable traders varies from $2 \mathrm{~kg}$ to 5 $\mathrm{kg}$. The fish are usually divided by fish sellers directly into plastic bags per $1 \mathrm{~kg}$ or $0.5 \mathrm{~kg}$. The price set by the fish seller to the motor vegetable trader is also different from 
Table 1. Fish species were recorded in the traditional market of Pasar Baru, Balikpapan, East Kalimantan, Indonesia

\begin{tabular}{|c|c|c|c|}
\hline Vernacular name*) & Common name & Scientific name \& family & $\begin{array}{l}\text { Habitat \& catch } \\
\text { technique }\end{array}$ \\
\hline Layur (PB) & Largehead Hairtail & Trichiurus lepturus Linnaeus 1758 (Trichiuridae) & Marine, Fishhook \\
\hline Serisik (PB), Selar, Selar bentong & Bigiye scad & Selar crumenophthalmus Bloch 1793 (Carangidae) & Marine, Fishing Net \\
\hline Sembulak (PB), Lemuru Jawa & Spotted sardinella & Amblygaster sirm Walbaum (Clupeidae) & Marine, Fishing Net \\
\hline Hambar (PB), Diles & Caraun crocer & Johnius carouna Cuvier 1830 (Sciaeinidae) & Marine, Fishing Net \\
\hline Alo-alo (PB), Alu-alu, Barakuda, Pengaluan, Lengko, Langsar & Barracuda & Sphyraena sp. (Sphiraenidae) & Marine, Fishhook \\
\hline Gembong (PB), Kembung & Mackerel & Rastrelliger sp. (Scrombidae) & Marine, Fishing Net \\
\hline Biji nangka (PB), Pisang-pisang & Goldband Fusilier & Pterocaesio chrysozona G. Cuvier 1830 (Caesionidae) & Marine, Fishing Net \\
\hline Tengiri (PB) & Cero Mackerel & Scomberomorus sp. (Scombridae) & Marine, Fishhook \\
\hline Layang pulau (PB), Bandeng laut, Selayang & Raibow runner & Elagatis bipinnulata Quoy \& Gaimard 1825 (Carangidae) & Marine, Fishing Net \\
\hline Layang $(\mathrm{PB})$ & Mackerel scad & Decapterus sp (Carangidae) & Marine, Fishing Net \\
\hline Tenggiri kawang (PB), Tenggiri papan, Tenggiri totol & Spotted seerfish & Scomberomorus guttatus Bloch \& Schneider 1801 (Scombridae) & Marine, Fishhook \\
\hline Tongkol (PB), Komo & Kawakawa & Euthynnus affinis Cantor 1850 (Scombridae) & Marine, Fishook \\
\hline Ame-ame (PB), Cikalang & Skipjack tuna & Katsuwonus pelamis Linnaeus 1758 (Scombridae) & Marine, Fishhook \\
\hline Trakulu/ Karakulu (PB), Kwee, Meye & Giant Trevally & Caranx ignobilis Forsskal 1775 (Carangidae) & Marine, Fishhook \\
\hline Trakulu lilin (PB), Kwee lilin & Hunchback Trevally & Carangoides gymnostethus Bloch \& Schneider 1801 (Carangidae) & Marine, Fishhook \\
\hline Kerapu (PB) & Highfin Grouper & Epinephelus maculatus Bloch 1790 (Serranidae) & Marine, Fishhook \\
\hline Kiper (PB), Ketang-ketang & Spotted Scat & Scatophagus argus Bennett 1830 (Scatophagidae) & Marine, Fishing Net, Fishhook \\
\hline Kambronang (PB), Baronang & Foxface Rabbitfish & Siganus vulpinus Schlegel \& Muller 1845 (Siganidae) & Marine, Fishing Net \\
\hline Ekor kuning (PB), Surili & Fusillier & Caesio sp (Caesionidae) & Marine, Fishing Net \\
\hline Belanak (PB), Bebenak & Green back Grey Mullet & Chelon subviridis Valenciennes 1836 (Mugilidae) & Marine, Fishing Net \\
\hline Como-como (PB), Selar como & Yellowtail Scad & Atule mate Cuvier 1833 (Carangidae) & Marine, Fishing Net \\
\hline Kakap raja (PB), Kakap merah & Scaret seaperch & Lutjanus malabaricus Bloch \& J.G Schneider 1801 (Lutjanidae) & Marine, Fishhook \\
\hline Kerapu merah (PB), Sunu merah & Coral Hind & Cephalopholis miniata Forsskal 1775 (Serranidae) & Marine, Fishing Net \\
\hline Alu-alu/ Barakuda kecil (PB), Barakuda, Langsar & Bigeye Barracuda & Sphyraena forsteri Cuvier 1829 (Acanthuridae) & Marine, Fishing Net 2 \\
\hline Kurisi (PB) & Japanese Threadfin Bream & Nemipterus japonicus Bloach 1791 (Nepteridae) & Marine, Fishing Net \\
\hline Bandeng (PB) & Milk fish & Chanos chanos Forsskal 1775 (Chanidae) & $\begin{array}{l}\text { Brackish, Raised in brackish } \\
\text { pond, Fishing Net }\end{array}$ \\
\hline Tuna (PB), Tuna Ekor Panjang & Longtail tuna & Thunnus tonggol Bleeker 1851 (Scombridae) & Marine, Fishhook 26 \\
\hline Patin $(\mathrm{PB})$ & Catfish & Pangasius pangasius H.B (Pangasidae) & Freshwater, Raised in fishpond \\
\hline Mujair (PB) & Mozambique Tilapi & Oreochromis mossambicus Peters 1852 (Cichlidae) & Freshwater, Raised in fishpond \\
\hline Nila (PB) & Nile Tilapia & Oreochromis niloticus (Cichlidae) & Freshwater, Raised in fishpond \\
\hline Ikan Mas (PB) & Common Carp & Cyprinus carpio C.V (Cyprinidae) & Freshwater, Raised in fishpond \\
\hline Bawal (PB) & Angelfish & Taractes sp (Bramidae) & Marine, Freshwater Fishing net \\
\hline Lele $(\mathrm{PB})$ & Clarias catfish & Clarias batrachus Linnaeus 1758 (Clariidae) & Freshwater, Raised in fishpond \\
\hline Haruan (PB), Gabus & Chevron Snakehead & Channa striata Bloch 1793 (Channidae) & Freshwater, Fishhook \\
\hline Kalwe (PB), Gurami & Gourami & Ostronemus gourami Lacepede 1801 (Osphronemidae) & Freshwater, Raised in fishpond \\
\hline Rampang (PB), Tawes & Tawes & Barbonymus gonionotus Bleeker 1849 (Cyprinidae) & Freshwater, Raised in fishpond \\
\hline
\end{tabular}

Note: *) PB: Vernacular name based on fish traders of traditional market of Pasar Baru, Balikpapan 
Table 2. Families and fishes are recorded traded in the traditional market of Pasar Baru Balikpapan, East Kalimantan, Indonesia

\begin{tabular}{llcc}
\hline \multicolumn{1}{c}{ Family } & \multicolumn{1}{c}{ Common name } & Species number & Percent of the total \\
\hline Acanthuridae & Surgeon fishes and Moorish Idols & 1 & 2.77 \\
Bramidae & Prom frets, Castagnoles, Tristones & 1 & 2.77 \\
Caesonidae & Fusilier & 2 & 5.55 \\
Carangidae & Jacks, Pompanos & 6 & 16.66 \\
Chanidae & Milkfishes & 1 & 2.77 \\
Claridae & Catfishes & 1 & 2.77 \\
Channidae & Snakeheads & 1 & 2.77 \\
Cichlidae & Cichlid fishes & 2 & 5.55 \\
Clupeidae & Haerings, Shads, Sardines & 1 & 2.77 \\
Cyprinidae & Carps & 2 & 5.55 \\
Lucanidae & Stag beetles & 1 & 2.77 \\
Mugilidae & Mullets & 1 & 2.77 \\
Nepteridae & Threadfin bream & 1 & 2.77 \\
Osphronemidae & Gouramis, Bettas & 1 & 2.77 \\
Pangasidae & Catfishes & 1 & 2.77 \\
Scaenidae & Croakers, Dreams, Jewfishes & 1 & 2.77 \\
Scatophagidae & Spotted Scat, Spotted Scad, Spotted Butt & 1 & 2.77 \\
Scrombidae & Mackerel, Tunas, Bonitos & 6 & 16.66 \\
Serranidae & Groupers, Sea bases & 2 & 5.55 \\
Siganidae & Rabbitfishes, Spinefoot & 1 & 2.77 \\
Spiraenidae & Bonnethead sharks, Hammerhead sharks & 1 & 2.77 \\
Trichiridae & Scabbard-fishes, Cutlass-fishes & 1 & 2.77 \\
Total & & 36 & 100.00 \\
\hline
\end{tabular}

the price given to private consumers. For example, if it is a private consumer, the fish seller will make a profit of Rp. 1000, - if you go to a vegetable seller, a fish seller will only take a profit of Rp. 500, -. Fish that are often bought by motor vegetable traders are ikan tongkol (Euthynnus affinis) and ikan kembung/gembong (Rastrelliger $\mathrm{sp}$ ).

\section{Fish species}

Based on the results of an inventory and interviews with fish traders, it was documented 36 species of fish, representing 22 families, which were traded in Pasar Baru Balikpapan, East Kalimantan (Table 1 and Table 2).

Total of 36 fish species traded in Pasar Baru consist of 26 species of marine fish $(72.22 \%)$ and 10 species of freshwater fish (27.78\%). In terms of family, based on 22 fish families, documented 6 families have high number of species, namely Carangidae (16.66\%), Scrombidae (16.66\%), Caesonidae (5.55\%), Cichlidae (5.55\%), Cyprinidae (5.55\%), and Serranidae (5.55\%) (Table 2).

In terms of diversity, based on the number of fish species traded in Pasar Baru, Balikpapan (36 species) compared to fish species recorded in the modern market Rokan Hulu, Riau, recorded 24 species of fish, consists of 7 species of sea fish $(29.16 \%)$ and 17 species of freshwater fish $(70.84 \%$ ), representing 14 families (Realita et al 2015); it can be seen that the diversity of fish species traded in traditional market of Pasar Baru is higher than that of trading in the modern market of Rokan Hulu, Riau. Likewise, the number of fish species in Pasar Baru is higher than that of the market of Pasar Parit 1, Kuala Tungkal, Jambi, Sumatra, recorded 23 species of sea fish representing 15 families (Maidika et al. 2016);
Regarding species compositions, it can be seen that fish species traded in Balikpapan are generally important economic fishes in Indonesia, such as layang (Decapterus ruselli), selar bentong (Selar crunemopthalamus), sunglir/salem (Elagatis bippinalatus), ikan merah/kappa merah (Luchanus malabaricus) ), komo /tongkol (Enthynnus affinis), and abu-abu (Thunnus tonggol) (Genisa 1999). Some species of marine and fresh-water fish, such as ikan mas (Cyprinus cario), lele (Clarias batrachus), and nila (Oreochromis niloticus) traded in Pasar Baru, Balikpapan, are also commonly traded in the Muara Tungkal market, Jambi and modern markets in Rokan Hulu, Sumatra (Realita et al. 2015; Maidika et al. 2016). In addition, some species of marine fish traded in the Pasar Baru traditional market, Balikpapan, Kualatungkal are also the main species of fish caught by fishermen in Bangka, Sumatra (Kurniawan et al. 2019). Meanwhile, various species of fresh-water fish traded in Pasar Baru, Balikpapan and Rokan Hulu Market, Riau show that there are species of raised fish in cages (karamba) and river wild fish, such as S. Mahakam fish, East Kalimantan, and Siak river, Riau (Kottelat 1995; Iskandar and Dhahiyat 2012).

On the basis of the results of the recording of fish species in Pasar Baru, Balikpapan, East Kalimantan and several markets in Sumatra, shows that biodiversity, such as the diversity of fish species traded in these markets have tended to a reflection of biodiversity diversity and cultural characteristics of the people in the region (cf. Albuquerque et al. 2014). 


\section{Local knowledge on fish}

Since the fish traders have experienced in trading for a long time intergeneration, they have local knowledge or Traditional Knowledge (TEK). Some TEK of the fish traders, including naming fish, fish habitat and caugh technique, sex difference, taste of fish, price of fish, origin of fish and processing, and freshness of fish and preservation.

\section{Naming fish}

Regarding naming fish based on traders, various species can be recognized various names, namely vernacular name and Indonesian names. Vernacular names of fish are predominantly given names based on vernacular names of South Sulawesi, due to most fish traders in Pasar Baru, Balikpapan is migrants from South Sulawesi. For example, Sphyrena sp is given name by the fish traders of Pasar Barus as alo-alo. This fish species, however, has also some local names, including barracuda, alu-alu, pengaluan, lengko, and langsar. In some cases, fish consumers also familiar with the vernacular name of alo-alo. However, if the consumer does not know concerning vernacular name of alo-alo, the seller will mention with common Indonesian name as barracuda. Thus, it can be observed when fish traders offer researchers who in fact are not local residents, they can sad "Come on Pak or Bu this is alo-alo fish, if you don't know the name of alo-alo, this is has another name as barracuda fish!" (Table 1). Some fish names also use common names in the mention of buying and selling activities every day, for example, ikan tongkol (Euthynnus affinis). There are also fish whose names are difficult to find in the dictionary or in common Indonesian names, such as ikan biji nangka (Pterocaesio chrysozona), although using Indonesian but when this name is checked on the Internet or a fish identification book, the species of fish are diverse and with the mention there also not one species. In other words, one vernacular name of fish can be given for several fish species, based on biological scientific name.

\section{Fish habitat and caught technique}

Based on folk classification, fish traded in the traditional market of Pasar Baru, can be classified based on their habitat and fishing techniques in the ecosystem (Table 1). Based on its habitat, the species of fish traded in Pasar Baru, can be classified into two main categories, namely the marine of fish that having a habitat on marine and freshwater fishes. Various species of marine fish, such as layur (Trichiurus lepturus), serisik (Selar crumenophthalmus), hambar (Johnius carouna), alo-alo (Sphyraena sp.), gembong (Rastrelliger sp.), biji nangka (Pterocaesio chrysozona) and tenggiri (Scomberomorus $\mathrm{sp}$ ) the main catches of fishermen from the marine in East Kalimantan, such as Botang and Berau, also from the waters of South Sulawesi. The species of marine fish caught by the fishermen are usually transported to Semayang port, Balikpapan, the distance is about $4.8 \mathrm{~km}$ from Pasar Baru or 15 minutes by motorized vehicle. In addition, species of marine fish aside from the Semayang port, also from the Manggar coastal area, Balikpapan. The distance from Pasar
Baru, about $15 \mathrm{~km}$ or 40 minutes using a vehicle from Pasar Baru, Balikpapan. towards traditional markets,

The species of sea marine are usually caught using fishing (pancing) and nets (jaring). Some large size, fish such as tarakulu fish and barracuda are usually caught by fishing line. Meanwhile, the species of small size fish, such as kembung (Rastrelliger sp) are usually netted. The season for many fish is usually in November-March.

Unlike the types of marine fish, freshwater fish species, such as mujair (Oreochromis mossambicus), nila (Oreochromis niloticus), ikan mas (Oreochromis niloticus), lele (Clarias batrachus), and haruan/gabus (Channa striata) usually their habitats in freshwater, such as in rivers and are raised in cages and caught by nets and rivers from the Banjarmasin, South Kalimantan, and rivers in the Balikpapan region, East Kalimantan. Generally, freshwater fish species are brought from fishing grounds and sold in the Newmarket, in a state of life. Therefore, the price of freshwater fish species is more expensive than the price of marine fish species

\section{Sex differentiate}

Based on fish trader perception, the sex differentiates of several fish species are also recognized by fish traders. The distinction of sex differentiate is mainly based on physical characteristics of fish. For instance, sex of ikan tenggiri (Scomberomorus guttatus) can be diagnostically recognized based on its physical characteristics. According to fish traders perception, male of ikan tenggiri has diagnostic characteristic, mainly it has long body features with vertical stripes on its stomach. Whereas for female of ikan tenggiri, she has diganostich characteristic, particularly she has shorter and slightly wider body features with dots on their belly (Figure 8).

\section{Taste of fish}

On the basis of fish trader perception, based on the folk classification, the fishes can be traditionally classified as 'taste good fish' (ikan enak rasanya) and 'taste bad fish' (ikan kurang enak rasanya). For example, ikan gembong/ kembung (Rastrelliger $\mathrm{sp}$ ) can be considered as taste good. Therefore, if the fish is cooked very simply it looks like fried it tastes good. Another fish, ikan layang (Decapterus sp.) is also considered as fish taste; thus if it simply cooked, given simple sauces, including chili, onion, sugar and shrimp paste, it may taste good. Conversely, several fish species, including ikan kipper/ketang-ketang (Scatophagus argus), based on fish trader perception as taste bade fish. Because this fish has a lot of fish bonds and thin flesh. Ikan kipper is usually caught in a net by fishermen unintentionally. Considering that kipper is not tasty, the price is cheap, and this fish is not specifically to be caught, the population in the market is not much. In addition to different species, fish sex differences also have different tastes. For example, male mackerel is perceived to have a better taste than the taste of female fish. 

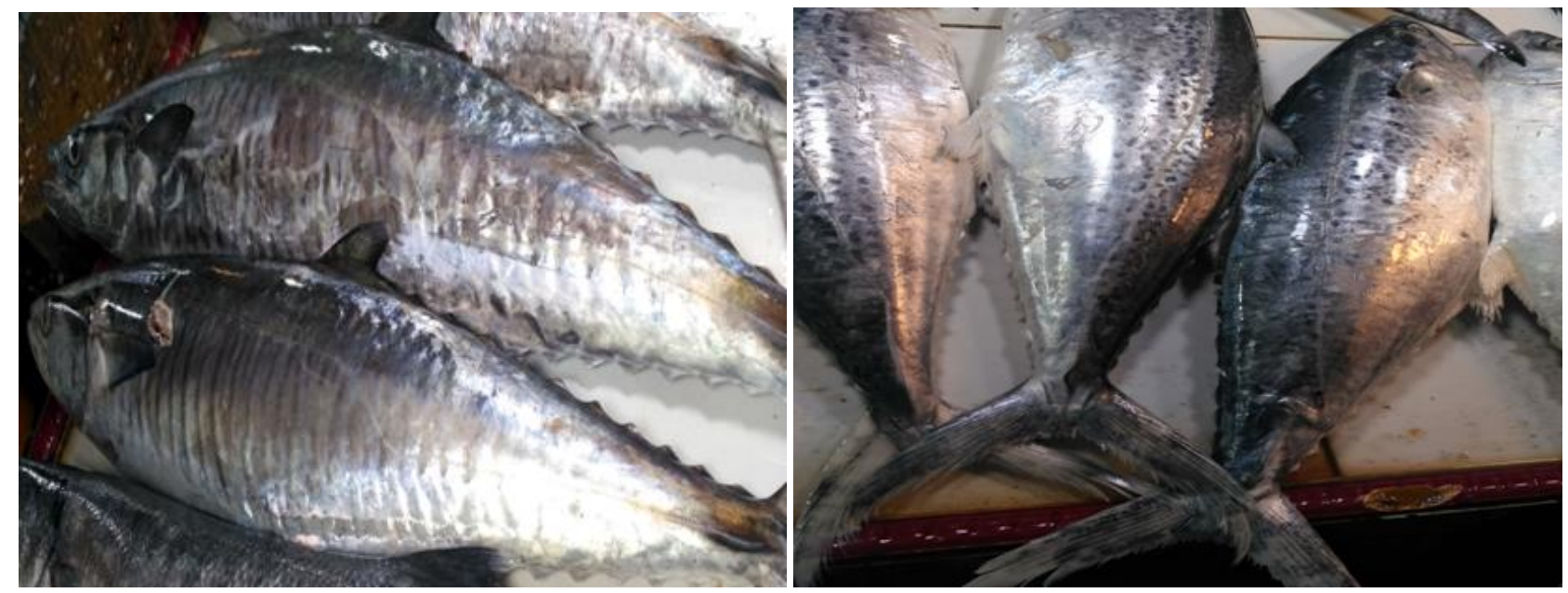

Figure 8. Male fish of Tengiri (Scomberomorus sp.) (left), and female Tengiri Fish (right)

\section{Price of fish}

The species of fish based on the classification of the traders can be divided into two main categories namely the species of fish that have high selling prices and species of fish that have low selling prices. For example, the fish of kerapu (Epinephelus maculatus) that has medium to large size, has a price of more than Rp 150,000/ kg. Several other species of fish are categorized as having high prices, including trakulu (Caranx ignobilis) and tenggiri (Scomberomorus sp), which are priced at $\mathrm{Rp} 60,000-\mathrm{Rp}$ 65,000 / $\mathrm{kg}$ and $\mathrm{Rp}$ 60,000-Rp 80,000, respectively. Conversely, the types of fish that are categorized as having cheap prices, such as mackerel, laying fish, and milkfish, sell for Rp. 20,000, Rp. 15,000 and Rp. 15,000, respectively. In addition, the differences in sex from several types of expensive fish also have different prices. For example, male mackerel can sell for $\mathrm{Rp} 80,000 / \mathrm{kg}$, while female mackerel sells for around $\mathrm{Rp} 60,000$. This is partly because male mackerel tastes better than female mackerel.

\section{Origin of fish and processing}

Various fishes traded in traditional market of Pasar Baru Berbagai can be divided into origin and appropriate for cooking. For example, fish traders in Pasar Baru Balikpapan have TEK of the origin of fish traded. This was found when the researchers entered the fish block and made observations, some visitors asked where the fish came from and how good it should be cooked. Traders also answer in detail the questions from the buyers. For example, ikan trakulu or ikan kwe (Caranx ignobilis) described by the fish merchants came from Berau waters and for large sizes caught by fishing, these fish are usually suitable to be cooked by burning or also cooked with sour sauce and pepper sauce. Such knowledge becomes important because directly and indirectly, the existence of such knowledge and conveyed by traders gives new knowledge to buyers or visitors.

\section{Freshness of fish and preservation}

On the basis of fish traders, various fishes traded in traditional market can be divided into the fresh fish (ikan segar) and not fresh fish (ikan tidak segar). Traditionally, fish traders in Pasar Baru, Balikpapan can recognize and have special techniques used to determine the freshness of fish. First, to see fish from their physical condition, and secondly, to see fish eye. According to fish trader perception, the fresh fish has a shiny body condition. Apart from the condition of the fish's body, traders can also find out the freshness of the fish through the eyes of the fish. The fresh fish have clear eyes, namely fish eyes that are not translucent or dull are usually a sign of fish that are old. If the fish trader is still not sure of the two signs mentioned earlier there is one more way, namely from the fish gills. The condition of fish gills that are still fresh red with blood that is still attached, to find out by opening the gill cover (opercula) or by pressing the opercula when bleeding, the fish is fresh (Figure 9).

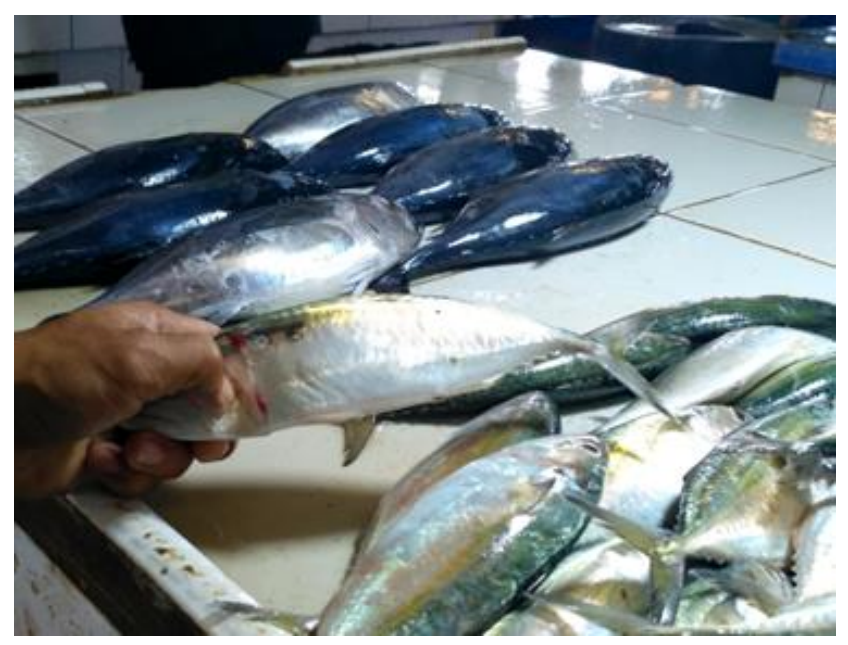

Figure 9. Pressing opercula (gill cover) to know fish freshness 
To maintain the fresh fishes, the traders usually use ice cubes to preserve fish for sale. These ice cubes are purchased from ice traders located in Pasar Baru, Balikpapan. The price of ice cubes sold to preserve fish is Rp1,000/unit. Traders preserve small to moderate fish using the wet preservation method, which uses water that is given ice cubes. Traders need 15 cubes of ice to preserve $40 \mathrm{~kg}$ of small to medium-sized fish. If the amount is less than the benchmark, the quality of fish will be damaged. For example, ikan kembung (Rastrelliger sp.), if the ice is given less than the stomach of the fish will be damaged. This causes the selling price to decrease and no longer last in the next few days. Unlike the preservation of small to moderate fish, some large fish are preserved using the dry method, which only uses ice cubes without water. For large fish traders need 20 ice cubes to preserve $40 \mathrm{~kg}$ of fish weight.

\section{Knowledge transmission and conservation of fish species}

Generally, every community has its own knowledge about the biodiversity that surrounds it. This is because humans and their daily lives constantly interact with the environment or the local ecosystem (Marten 2001). For example, every community has Traditional Ecological Knowledge (TEK) and its own mention of certain plants and animals. According to Berkes (2008), TEK is defined as a collection of knowledge, practices, and beliefs, which develops through the process of adaptation and is passed down from generation to generation by cultural transmission, about the relationship between living things (including humans) with one another and with the environment. TEK is dynamic, built on experience, and adaptive to change. TEK also gives different meanings and values to the biological entity. Considering information from ecosystems is usually perceived, interpreted, and named and interpreted for humans (Marten 2001; Yenrizal et al. 2015; Iskandar 2017). The TEK in the fish trading community, such as knowledge about species of fish can be transmitted in 3 ways, namely parental, peer and individual learning (Puri 1977; Iskandar and Iskandar 2005). Parental learning is the learning of knowledge through the process of parents/older siblings to their children or learning through vertical cultural transmission. Peer learning is the process of learning to share knowledge from peer groups or peer groups, adolescence. Furthermore, the independent learning process is independent of each individual or individual learning or horizontal cultural transmission.

Based on the experience of trading fish species in Pasar Baru, Balikpapan, fish traders can go through a process of parental, peer, and individual learning, in general, having local knowledge or TEK about species of fish, with various aspects, such as knowledge of fresh fish and not fresh; origin, method of capture, and processing recommendations; and how to preserve fish. This is in accordance with various ethnic groups in cross-cultural terms in the world, that in general the people who always interact with species of fish or fisheries have an in-depth knowledge of the names of fish species and various ecological aspects about fish (Silvano and Begossi 2005;
Kalanda-Sabola et al. 2007; Utomo 2010; Partasasmita et al. 2015). The species of fish in the Pasar Baru market, not only traded, the traders directly or indirectly also provide knowledge to buyers about the types of fish traded to the right processing. Therefore, the market is not only a place for economic turnover and the location of traders looking for income, but the market is also the arena of knowledge channeled and further recognition of fish species also pushes it towards conservation. In other words that given the traditional markets for the production of many species of plants and fish, traditional markets are important in addition to economic interests, it is also important for the conservation of local biodiversity (cf. Arman 1996; Iskandar et al. 2018).

On the basis of the study, it can be concluded that it has been documented at least 36 fish species, representing 22 families. Those species are considered as economic values in Indonesia. In general, fish traders have quite in-depth knowledge about the species of fish they trade. The fish traders in addition to having knowledge about fish species, also have knowledge of fish sex identification, origin of fish, how fish are caught, processing methods for consumption, freshness of fish, and how to preserve fish. Fish species have local names. The name of the local species of fish is based on the local knowledge they have. Traders also often offer fish to buyers by naming the species of fish, then indirectly the trader has transmitted knowledge about fish species to the wider community in the wider community in the market environment. In addition, given the traditional market diversity in fish markets is traded high. Thus, the traditional market is not only important for the economic function of the community, it also has a function for the conservation of local biological diversity such as the types of fish that are negotiated in the traditional market.

On the basis of the study, it can be concluded that it has been documented at least 36 fish species, representing 22 families. Those species are considered as economic values in Indonesia. In general, fish traders have quite in-depth knowledge about the species of fish they trade. The fish traders in addition to having knowledge about fish species, also have knowledge of fish sex identification, origin of fish, how fish are caught, processing methods for consumption, freshness of fish, and how to preserve fish. Fish species have local names. The name of the local species of fish is based on the local knowledge they have. Traders also often offer fish to buyers by naming the species of fish, then indirectly the trader has transmitted knowledge about fish species to the wider community in the wider community in the market environment. In addition, given the traditional market diversity in fish markets is traded high. Thus, the traditional market is not only important for the economic function of the community, it also has a function for the conservation of local biological diversity such as the types of fish that are negotiated in the traditional market. 


\section{ACKNOWLEDGEMENTS}

The authors acknowledge the SIMLITABMAS, Ministry of Research and Technology for funding the research project of Dr. Budiawati Supangkat Iskandar, Decree Number 10/E1/KP.PTNBH/2019 and Agreement/ Contract Number 5097c/UN6.G/LT/2019. We also like to thank all informants, namely the fish traders, fish porters, and fish consumers of Pasar Baru, Balikpapan, East Kalimantan for their corporation with this research.

\section{REFERENCES}

Albuquerque UP, Ramos MA, Paiva de Lucena RF, Alencar NL. 2014a. Methods and techniques used to collect ethnobiological data. In ethnobiological research in public markets. In: Albuquerque UP, Cruz da Cunha LVF, Paiva de Lucena RF, Alves RRN (eds) Methods and techniques in ethnobiology. Humana Press, Springer Science+ Business Media, New York.

Albuquerque UP, Monteiro JM, Ramos MA, de Amorim, Alves RRN 2014b. Ethnobiological research in public markets. In Albuquerque UP, Cruz da Cunha LVF, Paiva de Lucena RF, Alves RRN (eds) Methods and techniques in ethnobiology. Humana Press, Springer Science+Business Media, New York.

Alves RRN, Souto WMS. 2015. Ethnozoology: a brief introduction. Ethnobiol Conserv 4: 1-13. DOI:10.15451/cc2015-1-4.1-13.

Arman S. 1996. Diversity and trade of market fruits in West Kalimantan. In: Padoh C, Peluso NL (eds) Borneo in transition: people, forests conservation, and development. Oxford University Press, Kuala Lumpur.

Berkes F. 2008. Sacred ecology. Second Edition. Routledge, New York.

Brown CH. 2000. Folk classification: an introduction. In: Minnis PE (ed) Ethnobotany: a reader. University of Oklahoma Press, Norman, Oklahoma.

Carlson TJS, Maffi L. 2004. Introduction: ethnobotany and conservation of biocultural diversity. In: Carlson TJS, Maffi L (eds) Ethnobotany and conservation of biocultural diversity. The New York Botanical Graden Press, New York.

Edwards AR. 2010. Thriving beyond sustainability: pathways to a resilient society. New Society Publishers, Gabriola Island, Canada.

Fowler CS. 2000. Ethnoecology: an introduction. In: Minnis PE (ed) Ethnobotany: a reader. University of Oklahoma Press, Norman, Oklahoma.

Ellen R, Harris H. 2000. Introduction. In: Ellen EF, Parkes P, Bicker A (eds) Indigenous environmental knowledge and its transformation: critical anthropological perspective. Hardwood, Amsterdam.

Iskandar J. 2017. Human ecology and sustainable development. PSMIL, Unpad [Indonesian].

Iskandar J, Iskandar B. 20005. Alternative medicine in the style of Baduy. Humaniora, Bandung. [Indonesian]

Iskandar BS, Iskandar J, Irawan B, Partasasmita R. 2018. Traditional markets and diversity of edible trading: case study in Ujung Berung, Bandung, West Java, Indonesia. Biodiversitas 19 (2): 437-452.

Iskandar J, Dahiyat Y. 2012. Fish diversity in Siak river, Riau. Bionatura J Ilmu-ilmu Hayati dan Fisik 14(1): 51 - 58.

Kalanda-Sabola MD, Henry EM, Kayambazinthu E, Wilson J. Use of indigenous knowledge and traditional practices in fisheries management: a case of Chisi Island, Lake Chilwa, Zomba. Malawi J Sci Technol 8: 9-29.

Kottelat M. 1995. The fishes of Mahakam river, East Borneo: an example of the limitations of zoographic analyses and the need for extensive fish surveys in Indonesia. Trop Biol 2 (3): 401-426.
Kottelat M, Whitten AJ, Kartikasari SN, Wirjoatmodjo S. 1993. Freshwater fishes of Western Indonesia and Sulawesi. Periplus Editions, Singapore.

Kurniawan, Asmarita, Supratman. 2019. Fish species identification (local, national and scientific naming) fishermen main capture (HTU) and fishing equipment classification in Bangka Island, Province of Bangka Belitung Island. Akuatik J Sumberdaya Perairan 13 (1):42-51 [Indonesian]

Maidika D, Siburian J, Hamidah A. 2016. Study of fish species at parit 1 Kuala Tungkal market for high school. Bioedukasi 9(2): 27-33.

Marten GG. 2001. Human ecology: basic concepts for sustainable development. Earthscan Publications Ltd., London.

Miles MB, Huberman AM. 1992. Analisis data kualitatif. UI Press, Jakarta. [Indonesian]

Milton K. 1996. Environmentalism and Cultural Theory: Exploring the Role of Anthropology in Environmental Discourse. Routledge, London.

Nabhan GP. 2016. Passing on a sense of place and traditional ecological knowledge between generations. In: Nabhan GP (ed) Ethnobiology for The Future: Linking Cultural and Ecological Diversity. The University of Arizona Press, Tucson.

Newing H, Eagle CM, Puri RK, Watson CW.2011. Conducting Research in Conservation: a Social Science Perspective. Routledge, London.

Nurasa T. 2005. Fresh sea fish marketing in traditional market of DKI Jakarta. Indonesian Center for Agricultural Socio-economic and Policy Studies (ICASEPS), Department of Agriculture, Jakarta [Indonesian].

Partasasmita R, Nuari T, Tatang SE, Johan I. 2015. The diversity of fish species and the disturbances in the Cikawung river, Cianjur, West Java, Indonesia. Nusantara Biosci 7: 165-170.

Puri RK. 1977. Hunting Knowledge of Punan Benalui of East Kalimantan Indonesia. [Dissertation] Department of Anthropology at the University of Hawaii, USA.

ealita, Ade FY, Dahlia. 2015. fresh fish species traded in the modern market of Rokan Hulu Regency, Riau Province. E J Student Biol Study Program, FKIP, University of Pengarai 1 (1): 1-4. [Indonesian]

Sawada T. 1980. Fishes in Indonesia (with illustrations). Japan International Corporation, Tokyo

Schuster WH, Djajadiredja RS. 1952. Local common names of Indonesian fishes. NV Penerbit W. van Hoeve-'s-Gravenhage, Bandung.

Sillitoe P. 2002. Globalizing indigenous knowledge. In: Sillitoe P, Bicker, Pottier J (eds) Participating in Development Approaches to Indigenous Knowledge. Routledge, London.

Silalahi M, Nisyawati, Waluyo EB, Supriatna J. 2015. The local knowledge of medicinal plant trader and diversity of medicinal plants in the Kabanjahe traditional market, North Sumatera, Indonesia. J Ethnopharmacol 175: 432-443.

Silvano RAM, Begossi A. 2005. Local knowledge on a cosmopolitan fish ethnoecology of Potamus saltrix (Pomatidae) in Brazil and Australia. Fisheries Res 71:43-59.

Supangkat-Iskandar B. 1998. Women in the Market (Case Study in Ujung Berung, Bandung, West Java, Indonesia. [Thesis]. University of Kent, Canterbury, UK.

Supangkat B. 2012. Market and Women Traders in Ujung Berung Market, Bandung. [Dissertation]. Department of Anthropology, Faculty of Social and Political Sciences, University of Indonesia, Depok [Indonesian]

Utomo PB. 2010. The Role of Traditional Knowledge in Fisheries Management: A Study Case of Panglima Laot (Sea Commander) in the Aceh Province of Indonesia. [Dissertation]. World Maritime University, Skåne County, Sweden.

Warren DM, Slikkerver LJ, Brokensha (eds). 1995. The cultural dimensions of development: indigenous knowledge systems. Intermediate Technology Publications, London.

White WT, Last PR., Dharmadi, Farizah R, Chooriyah U, Prisantoso BI, Pogonoski JJ, Puckckridge M, Blaber SJM. 2013. Market fishes of Indonesia. ACIAR Monograph No. 155. Australian Centre of International Agricultural Research, Canberra. 